\title{
영국정부 개발원조 백서 발간
}

1. 영국 국제개발부(DFID)는 7.13 개발원조 백서 (White Paper on Inter - national Development)를 발간하였으며, 주요내용을 별 첨 보고함.

※www.dfid.gov.uk/wp2006/default.asp 에서 백원본은검색 가능

- 백서의 전체 제목은 "Eliminating world poverty: making governance work for the poor"로서, 금번 백서는 지난 2000년 백서 발간 이후 6 년 만에 새로이 발간되어 영국 정부의 향후 원조정책의 방향과 비전 제시

2. 백서는 빈곤퇴치를 위해 달성해야 할 과제를 네 가지로 분류하고, 각각의 과제를 영국 정부 가 어떻게 해결해 나갈 것인지에 대한 방향을 제시하는 형태로 구성됨.

- chapter 1에서는 2005년 글렌이글스 정상회 의에서 합의된 선진국의 개도국 지원 공약과
현재까지의 진전 상황에 대해 언급

- 나머지 chapter는 빈곤퇴치를 위해 달성해 야 할 4대 과제 (1) 빈곤 국민을 위해 일할 수 있는 국가건설(善政), (2) 평화와 안전의 증진 및 경제성장 촉진, (3) 기후변화에 대한 공동 대응, (4) 효율적인 국제개발 시스템 구 축)별로 1-2개의 chapter 할당

3. 금번 백서의 주요 특징은 (1) 일반 빈곤국민들 에 대한 효과적 원조 제공을 위해 개도국 정부 의 부패, 善政 등의 문제가 중점 부각되었다는 것과 (2) 기후변화문제를 거론하여 환경과 빈곤 의 관계 그리고 환경과 원조효과에 대한 관계 를 부각시켰다는 것이며, 또한 (3) 다자기구를 통한 원조 확대 필요성과 이를 효율적으로 시 행하기 위한UN, EU 등의 개혁 필요성을 부각 시켰다는 것 등으로 평가됨. 


\section{〈영국 국제개발원조 백서 주요내용〉}

\section{2005년도 공약의 이행 (Chapter 1)}

가. 영국정부는 2005 년 글렌이글스 G8 정상회의 에서 합의된 원조공약사항을 이행하도록 노 력할 것이며, 여타 관련국들에 대해서도 동일 한 노력을 계속 촉구해 나갈 것임.

나. 영국 정부는 개발원조 예산을 2013년까지 $\mathrm{GNI}$ 의 $0.7 \%$ 로 확대하고, 원조 대상은 사하 라 이남의 아프리카와 남아시아 그리고 분쟁 에 취약한 국가들에 집중할 것임.

다. 신약개발, 기후변화 대응 노력 등을 포함하여 천년개발목표(MDGs) 달성을 위한 과학기술 연구에 대한 재정지원을 2010년까지 두배로 증가시킬 것임.

\section{2. 빈곤 국민을 위해 일할 수 있는 국가건설 (善政) (Chapter 2\&3)}

\section{가. 효율적인 국가 및 善政 구축}

1) 善政은 정부기관만이 아니라 정당, 의회, 사법 기관, 언론, 시민사회 전반에 해당하는 것으 로, 국가의 역량(capability, 특정 기능을 수행 할 수 있는 능력), 대응성(responsiveness,
국민들의 희망과 수요에 대한 고려), 책임성 (accountability, 이행된 성과에 대한 책임) 등을 요건으로 함.

※ 백서에서는 governance의 개선을 이룬 성공사례로 한국을 포함한 동아시아 언급

("East Asian countries, such as Malaysia and South Korea, have changed the lives of millions of their citizens.")

2) 영국정부는 향후 원조 여부 결정시 원조대상 국가의 빈곤 감소를 위한 신념, 인권신장과 국제 의무에 대한 신념, 공공금융관리 개선 · 선정과 청렴 · 부패 추방에 대한 신념을 고려 할 것이며, 이에 대한 구체 평가에는 '통치체 제의 질' 평가( 'quality of governance' assessment) 기법을 이용할 것임.

3) 원조대상 국가의 통치체제에 대한 평가를 기 반으로 원조형태나 방법을 달리할 것임.

(1) 통치체제가 양호하다면 이는 장기적이고 예측 가능한 형태로 원조대상국가의 자체 시스템을 통해 직접적 예산지원(direct budget support) 고려

(2) 통치체제가 썩 양호하지 않다면 특정 프로 그램에 한정된 원조를 제공하거나 사업평 가와 회계감사를 강화하는 형태로 진행 (3) 대상국가 정부의 신념이 전혀 없는 경우 
정부와는 전적으로 별도로 추진하고 국제

기구와 연계하여 시행

4) 부패는 나쁜 통치의 근원인 동시에 그 징후이

며, 영국 정부는 회계감사의 투명성 점검, 부 패의 사법적 해결 지원, 부패척결노력 평가결 과의 원조정책 반영 등을 통해 개도국의 부패 척결을 위해 노력할 것임.

\section{나. 선정에 대한 국제적인 지원}

1) 통치의 문제는 국제적인 이슈로서, 개도국의 통치능력이 미약하여 국내 입법이나 규정이 충분치 못한 상황이라면 국제적인 거래관행 이나 지침이 도움이 될 수 있음.

a 예를 들어, 개도국 국내 입법의 허점을 악 용한 무기 거래가 이루어지고 이는 분쟁을 악화시키는 형태로 이용되고 있으므로, 영 국정부는 UN 총회에서 무기거래조약 (Arms Trade Treaty)에 대한 논의가 시작 되도록 노력할 예정임.

- 영국정부는 개도국에 영향을 미치는 부패 문제에 대처하기 위해 연간 Action Plan을 발간할 것이며, 2006년말까지 City of London, 런던 경시청 소속의 경찰로 구성 되는 해외부패 전담부서를 설치할 예정임.

2) 개도국의 천연자원이 잘못 관리되어 저주 (curse)로 간주되는 경우가 많아 합리적 관리 를 위한 국제사회의 노력이 필요함.
- 영국정부는 채취산업투명성기구(EITI: Extractive Industries Transparency Initiative, 산유국 정부와 석유기업의 자금 흐름을 투명하게 하고자 하는 취지로 토니 블레어 총리가 2002년 제안하여 출범)가 good management의 국제적 표준이 될 수 있도록 UN 총회 결의를 주도할 것이며, $\mathrm{EITI}$ 의 상설사무국 구성도 추진할 것임.

\section{3. 평화와 안전의 증진 및 경제성장 촉진} (Chapter 4\&5\&6)

\section{가. 평화와 안전의 증진}

1) 개도국의 발전을 위해서는 안전의 확보가 불 가결하며, 이를 위해서는 개도국의 정부기관 (국민의 안전과 정의를 책임질 수 있는 경찰, 군, 국경통제, 사법체계 등) 건설 지원 및 국 제사회의 분쟁 방지 능력 확보 등 두 가지 과 제를 해결해야 함.

2) 정부기관 건설 과제를 위해 영국 정부는 개도 국의 안보 관련 기구 개혁, 무기확산 방지, 무 장요원 해체, 사회적 소외 및 과격화 예방 등 을 지원하는 데 향후 원조의 우선순위를 부여 할 것임.

3) 국제사회가 분쟁방지 능력을 확보할 수 있도 록 하기 위해 영국 정부는 아래와 같은 노력 을 추구할 것임. 
- '보호할 책임' (responsibility to protect, 2005년 UN 정상회의에서 합의)에 대한 합의가 실제 행동으로 옮겨질 수 있도록 노력

- 국제기구와의 공조를 통해 분쟁에 취약한 국가에 대한 모니터링 강화, 분쟁당사자간 중재노력 강화

- UN 평화구축위원회(Peacebuilding Commission)에 대한 외교적 - 재정적 지 원 강화

\section{나. 경제성장을 통한 빈곤감소}

1) 교역과 개방은 경제성장의 관건이며, 개도국 경제성장과 관련해서는 빈곤국 경제성장의 가속화(grow faster), 빈곤층에 대한 경제성 장의 혜택 부여, 천연자원의 지속가능한 이용 에 기반을 두는 성장, 개도국에게 이익이 되 는 공정한 국제무역체제를 위한 협상, 성장을 이루기 위한 이민 관리 등 다섯 가지의 과제 를 안고 있음.

2) 영국 정부는 성장을 원조의 '탈출전략' ( 'exit strategy')으로 간주하며, 경제성장 가속화를 위해 개도국의 투자환경 개선 노력 지원, 사 회기간시설에 대한 투자확대, 과학기술분야 지원확대, 민간부문 발전과 고용증진 방안 강 구 등의 노력을 전개할 예정임.

3) 불평등은 사회적 갈등을 유발하는 문제로서 ' 성장은 지금, 분배는 나중'이 아니라 처음부
터 모든 사람들에 대한 경제적 기회를 확대해 야 함. 영국 정부는 이를 위해 근로조건 개선 과 소액금융지원(microfinance) 을 강화할 것임.

4) 영국 정부는 국제무역이 성장에 절대적이라 는 인식 하에 $\mathrm{DDA}$ 협상이 개도국에 이익이 되도록 노력하고, $\mathrm{EU}$ 의 공동농업정책이 빈 곤국에 혜택을 주는 방향으로 개혁되도록 노 력할 예정임.

\section{다. 인적자원에 대한 투자}

1) 영국 정부는 교육, 의료, 상하수도 설비, '사 회적 보호' (social protection) 등 네 가지를 MDGs 달성을 위한 필수적인 공공 서비스로 간주하며, 이러한 공공 서비스에 대한 지출 규모가 전체 영국정부의 대개도국 직접 지원 의 절반에 이르도록 할 예정임.

2) 교육은 권리임과 동시에 빈곤으로부터의 탈 출구인바, 향후 10 년간 85 억 파운드의 예산 지출을 포함하여 여학생 증가, 직업교육 강화 등의 프로그램을 지원할 예정이며, 의료분야 에서는 향후 10 년간 5 백만명의 생명을 구할 것으로 기대되는 '백신을 위한 국제재정지 원' (IFFIm) 계획을 실행에 옮기고, HIV 예방 /치료를 이끄는 국제적 노력(UNAIDS)도 지 원할 예정임.

3) 전세계 11 억명이 안전하지 않은 물을 음료하 고 있고, 이로 인해 5 세 이하 아동의 사망이 
매일 5,000 명에 이르고 있어 영국 정부는 개 도국의 안전한 상하수 설비를 확보하도록 지 출을 확대할 예정이며(2010/11년까지 2억파 운드), 아프리카 개발은행과 NGO 등에서 시 행하는 상하수도 개선프로젝트도 지원할 예 정임.

\section{4. 기후변화에 대한 공동 대응 (Chapter 7)}

가. 기온상승, 강우량 감소 등 기후변화 현상은 개도국의 식량, 건강, 개발에 심각한 영향을 주게 되며, 영국은 개도국과의 기후변화 대응 책 마련 노력(G8+5 회의 등)을 지속하고, 청 정에너지 개발 노력을 지원할 예정임.

나. 개도국이 기후변화의 영향에 적응(adaptation, 주민들의 생활에 미치는 기후변화의 위험을 줄여나간다는 의미)하기 위해서는 경제구조 다변화(economic diversification)와 대체작 물에 대한 투자 등과 같은 노력이 필요하나, 기후변화가 빈곤과 경제성장에 미치게 될 영 향에 대한 인식 제고도 필수적임.

다. 영국 정부는 $\mathrm{UN}, \mathrm{EU}$, 다자 개발은행들과 함 께 기후변화 영향에 대한 개도국의 인식 제고 와 개도국의 기후변화에 적응 노력을 지원할 것이며, 자연재해 발생에 따른 복구에 엄청난 비용이 소요되므로 재해 발생 이전에 이에 대 비하는 노력에도 지원을 확대할 예정임.

\section{5. 효율적인 국제개발 시스템 구축 (Chapter 8)}

※ 전 세계 개도국 원조비율 : 양자( $74 \%)$, 다자( $26 \%)$

- 양자 : 영국 7\%, 영국 이외 $\mathrm{OECD} \mathrm{DAC(63 \% ),}$ 여타국가(4\%)

- 다자 : EC (10\%), World Bank(9\%), UN (4\%), 기타 (3\%)

가. 21 세기 국제사회의 다양한 시대적 변화에 부 응하도록 국제기구가 효율적으로 변해야 하 며, 특히 국제개발원조 시스템은 아래 다섯 가지의 역할을 수행할 수 있어야 할 것임.

1) 높은 수준의 개발원조를 효율적으로 시행하 고, 그 결과를 보여주어야 하며,

2) 개도국들의 이해관계를 반영하고 스스로 개 발을 주도할 수 있도록 지원해야 하며,

3) 각국이 공약한 사항들에 책임을 지도록 해야 하며,

4) 인권과 여타 국제기준을 확인하고 기준이 충 족되지 않을 경우 조치를 취해야 하며,

5) 빈곤감소를 위해 합의된 목표가 어떻게 진전 되고 있는지 감독해야 함.

나. UN은 분쟁예방 - 평화중재 · 인도주의적 지원을 강화하고 인권분야에서처럼 국제적인 협정과 기준을 개발하는데 더욱 중점을 두어 야 하며, 이를 위해서는 UN의 개혁이 필 요함. 
- UN 산하기관과 원조 프로그램의 합리화도 필요한데, 각 개도국에 대해 단일한 조직과 예산으로 단일한 프로그램이 시행되도록 통 합 시스템을 갖추어야 함.

다. World Bank와 IMF가 개발원조에 있어 중대 한 역할을 지속하기 위해서는 장기적이고 예 측가능한 형태의 원조 제공, 중소득국들에 대 한 자금지원 편의 제공(중소득국들의 개발자 금 확보창구로 World Bank의 매력 감소 추 이), 청정에너지 및 기후변화 적응분야에 대 한 자금 지원 집중 등의 과제에 대응해 나가 야 하며, 영국정부는 World Bank와 IMF가 이러한 과제를 수행하는 것을 지원하고, 이들
기구내 개도국들의 발언권 강화를 위해서도 노력할 예정임.

라. 영국정부는 EU의 원조시스템이 국제적인 원 조를 주도할 수 있도록 개혁되어 한다는 생각 으로 이를 위해 회원국들과 협력해 나갈 것이 며, 국제개발기구에서의 $\mathrm{EU}$ 의 영향력 증대 를 위해서도 노력할 예정임.

마. 영국정부는 원조의 효율성 증대를 위해 합의 된 Paris Declaration (2005.3월)의 이행을 위해 여타국과 협력할 것이며, 원조 공약에 대한 이행 감독을 위해 OECD DAC의 역할이 강화되도록 노력할 예정임. 